2010

\title{
Tax Levels, Structures, and Reforms: Convergence or Persistence
}

Neil Brooks

Osgoode Hall Law School of York University, nbrooks@osgoode.yorku.ca

Thaddeus Hwong

Source Publication:

Theoretical Inquiries in Law. Volume 11, Issue 2 (2010), p.791-821.

Follow this and additional works at: https://digitalcommons.osgoode.yorku.ca/scholarly_works (c) (1) $(9)$

This work is licensed under a Creative Commons Attribution-Noncommercial-No Derivative Works 4.0 License.

\section{Recommended Citation}

Brooks, Neil, and Thaddeus Hwong. "Tax Levels, Structures, and Reforms: Convergence or Persistence." Theoretical Inquiries in Law 11.2 (2010): 791-821.

This Article is brought to you for free and open access by the Faculty Scholarship at Osgoode Digital Commons. It has been accepted for inclusion in Articles \& Book Chapters by an authorized administrator of Osgoode Digital Commons. 


\title{
Tax Levels, Structures, and Reforms: Convergence or Persistence
}

\begin{abstract}
Neil Brooks* and Thaddeus Hwong**
One of the central issues in comparative law and political economy is whether the forces of globalization will result in the convergence of public policies across countries. Noting in particular that taxes collected still cover a considerable range across industrialized countries - from a low of $20 \%$ of GDP to a high of $50 \%$ - some have argued that globalization has not resulted in a loss of tax sovereignty. However, following a review of the evidence, in this Article we conclude that globalization has had significant but subtle effects on tax levels and structures. Moreover, these pressures will make it increasingly difficult for countries to raise revenue to finance new public needs and to structure their tax systems in order to achieve a more socially acceptable distribution of income than what market forces dictate. Tax levels in most countries have remained essentially flat over the past twenty years, but there is a host of reasons for thinking they would have continued to rise were it not for the pressures of globalization. Statutory corporate tax rates have declined dramatically and, although corporate tax revenues have remained robust, this has been due to factors unrelated to deliberate tax policy choices. Personal marginal tax rates have also declined sharply and tax revenues have been increasingly raised by regressive consumption taxes. These trends stem from tax competition brought on by the forces of globalization, not from changing ideas or other political variables. In this Article we conclude that in order to prevent tax competition from completely eroding the ability of countries to fashion their own tax systems, there will have to be considerable cooperation among the major countries and some harmonization of aspects of their tax systems, particularly as they apply to footloose factors of production.
\end{abstract}

* Neil Brooks teaches tax law and policy at Osgoode Hall Law School, York University, Canada, and is a Senior Fellow of the Taxation Law and Policy Research Institute, Monash University.

** Thaddeus Hwong teaches tax law and policy at Faculty of Liberal Arts and Professional Studies, York University, Canada, and is a Fellow of the Taxation Law and Policy Research Institute, Monash University. 


\section{The Crisis of the Modern Tax State}

Over the past thirty years the world has become increasingly globalized. Although the term globalization has been used to describe a range of economic, political, social, ideological, cultural and technological changes that have caused the countries of the world to become much more closely knitted, in economic terms three connected developments have greatly intensified over the past few decades and have become the defining hallmarks of the contemporary international economy: (1) the liberalization of markets and the globalization of trade, (2) the dramatic increase in long-term foreign direct investment and the globalization of production, and (3) the increase in the mobility of financial capital and the globalization of capital and financial markets. These trends have heightened national competition over financial capital, the location of business, high-skilled labor, and ways of reducing the costs of production.

In light of these changes in the global economic environment, one of the most pressing issues in the study of comparative law and political economy has become the extent to which countries are still able to legislate autonomously to further the social goals of their citizens while achieving acceptable levels of economic growth. Many commentators argue that the powerful set of social and economic forces accompanying globalization are requiring countries to converge towards one singular governing model - the neo-liberal model - in which private ordering processes, such as markets, civil society, and the family, are the dominant forms of social organization. These exponents of convergence argue that the environmental forces that have led to increased economic integration limit the ability of national governments to act independently, and that a process of homogenization among countries will eventually lead to a so-called race to the bottom.'

\section{REVIEW OF THE DEBATE}

In comparative political economy, countless studies have been undertaken over the past fifteen years - indeed it was one of the academic growth industries of the 1990s - testing the convergence hypothesis; examining how aspects of the welfare state, such as unemployment insurance, old-age pensions, and public healthcare systems, have stood up; and attempting to

1 For a review of the arguments in support of the race to the bottom see Daniel W. Drezner, Globalization and Policy Convergence, 3 INT'L STUD. REV. 53 (2001). 
explain the trajectories in different countries. Contrary to the predictions of the exponents of convergence, in the late $1980 \mathrm{~s}$ and $1990 \mathrm{~s}$ some researchers found that while there were shifts in social policies, the basic institutions of the welfare state appeared to remain intact. This, in turn, led to a spate of literature attempting to explain welfare state persistence and retrenchment in the face of globalization and other forces for convergence. The broad theories that became prominent in this literature emphasized the importance in individual countries of prevailing ideas, domestic interest groups, unique political institutions and inertia. ${ }^{2}$

This debate over the effects of globalization on state sovereignty has been taken up in several strands of the tax literature, most notably in the literature on tax competition and harmonization. Those who expound the convergence thesis in this context argue that as a result of increased tax competition, governments will be pressured to reduce taxes generally; personal tax rates will be flattened so as not to encourage the emigration of high-income individuals; taxes on capital income will be reduced as countries compete for corporate investments and as the increased mobility of capital makes enforcement of capital taxes difficult or impossible; and there will be a shift to immobile and more regressive tax bases such as consumption, payrolls and real property.

This debate has been joined at two levels. At one level, there is a debate over whether tax competition has in fact reduced the ability of governments to fund the welfare state. A frequently cited article making the case that it has is Reuven Avi-Yonah's Globalization, Tax Competition, and the Fiscal Crises of the Welfare State, published in 2000 in the Harvard Law Review. ${ }^{3}$ Others, particularly a number of political scientists studying comparative tax political economy, have argued that countries still do have a good deal of freedom in setting their tax structures; they point to the facts that generally tax levels have not declined, corporate tax revenues have remained high, and there is no clear indication of a shift from taxing mobile to immobile factors. They conclude that there is no significant pressure on taxes and states are still free to pursue their desired redistributive and other social policies. ${ }^{4}$ At another

2 See generally Layna Mosley, Globalization and the State: Still Room to Move?, 10 NEW POL. ECON. 355 (2005).

3 Reuven S. Avi-Yonah, Globalization, Tax Competition, and the Fiscal Crises of the Welfare State, 113 HARV. L. REV. 1573 (2000).

4 Geoffrey Garrett \& Debora Mitchell, Globalization, Government Spending and Taxation in the OECD, 39 EuR. J. POL. REs. 145 (2001); DuANE SWANK, GlOBAL Capital, Political institutions, and Policy Change in Developed Welfare States (2002); Duane Swank \& Sven Steinmo, The New Political Economy of Taxation in Advanced Capitalist Democracies, 46 AM. J. POL. SCI. 642 (2002). 
level, the debate over tax competition has been joined by those who think it promotes - indeed it is essential to - government efficiency and those who regard it as an obstacle to democratic governance. ${ }^{5}$

In this Article, we deal principally with issues relating to the first level of this debate. In particular, as a contribution to this debate, we survey the evidence regarding changing tax levels and tax structures in the major Western industrialized countries over the past thirty years. We conclude that countries still do have some freedom in determining the level of taxes they can impose and, therefore, the level of public services that they wish to provide, but that globalization has had significant, but subtle, effects on tax levels and structures. Consequently, it would appear that if countries wish to retain their ability to use their tax systems to finance expanding government services, redistribute income and constrain corporate power, they will have to engage in a considerable amount of cooperation and agree to some harmonization of tax structures.

\section{Methodology}

In examining the effects of globalization on tax levels and structures, we compare nineteen high-income, large industrialized countries of the Organisation for Economic Co-operation and Development (OECD). Reliable comparisons are relatively easy for these countries since the OECD collects comparable tax data from its member countries, and has done so for all years since 1965 . Also, since these countries are relatively affluent, stable democracies they share a wide range of social, economic and political institutions. Thus, by comparing only these OECD countries, some general variables can be held constant such as a fundamentally capitalist and advanced industrial economy, and a broadly defined Western cultural heritage.

The OECD is comprised of thirty countries; however, a number of them that were admitted in recent years are less industrialized than others. In order to include only countries at a similar stage of economic development, countries with less than $\$ 25,000$ GDP per capita in USD PPP in 2007 were excluded. That eliminated the Czech Republic (joined in 1995), Hungary (1996), Korea (1996), Mexico (1994), Poland (1996), the Slovak Republic (1995), and Turkey (1961).

5 Compare Chris Edwards \& Daniel J. Mitchell, Global TAX Revolution: The RiSE OF TAX COMPETITION AND THE BATTLE TO DEFEND IT (2008) with Diane Ring, What's at Stake in the Sovereignty Debate? International Tax and the Nation-State, 49 VA. J. INT'L L. 156 (2008). 
Although the countries compared are similar in terms of their institutions, they differ widely in size. Two OECD countries, Iceland and Luxembourg, were excluded since, although they are relatively wealthy countries, they are essentially small cities with populations of only about 300,000 and 500,000, respectively. Japan and Switzerland were also excluded as they were found not to fit easily into any of the welfare state groupings that we use in the time period examined, even though their outlier status has diminished somewhat in recent years. ${ }^{6}$

Still, the remaining countries range in size from the U.S. - with a population of over 300 million - to Ireland, New Zealand, Norway, Denmark and Finland - each with a population of less than or only slightly more than 5 million. Although they differ widely in size, we made no effort to weight the tax structures of the countries by reference to their population or the size of their economies since the point of the comparisons is to derive conclusions about the effect of globalizing economic forces on national government policies.

Although the nineteen countries we examine share a number of features, they obviously differ in important respects. In the field of comparative political economy, a mini-discipline has developed attempting to categorize countries according to their primary ideological inspiration, dominant forms of social organization, central institutions, focus of their programs, aggregate welfare spending, institutionalization of social rights, and/or aspects of their economic and corporate governance and financial systems. During the 1990s, when the role of the welfare state underwent a thorough reevaluation, work on the resilience of different welfare regimes gained considerable prominence. The point of departure was provided by Gøsta Esping-Andersen's The Three Worlds of Welfare Capitalism in $1990{ }^{7}$

Esping-Andersen classified nations largely based upon his so-called decommodification index, which measures the extent to which the welfare of individuals in particular countries is reliant on the market, particularly in terms of the availability and generosity of public pensions, unemployment benefits and sickness insurance. He found that the groupings of countries were similar when he examined the role of the welfare state in maintaining or breaking down social stratification and the relative roles of the state, the family, the voluntary sector, and the market in welfare provision.

6 Francis G. Castles \& Herbert Obinger, Worlds, Families, Regimes: Country Chusters in European and OECD Area Public Policy, 31 W. Eur. POL. 321, 321-44 (2008).

7 Gøsta Esping-Andersen, The Three Worlds of Welfare CaPitalism (1990); see also GøSTA EsPing-Andersen, Social Foundations of Postindustrial ECONOMIES (1999). 
Based on this analysis, he classified advanced capitalist societies into three types: social democratic (largely the Nordic countries), liberal (largely the Anglo-American countries), and conservative (largely Germany and other Continental European countries). A number of authors subsequently identified an additional distinct regime, namely the Mediterranean model (Portugal, Spain, Greece and to a limited extent Italy). ${ }^{8}$ A vigorous debate has taken place over the number and the alternative regime types into which it is helpful to categorize modern welfare states, ${ }^{9}$ indeed some have questioned the value of the exercise at all ${ }^{10}$ nevertheless, the features of modern welfare states captured in the four widely accepted categories of welfare regimes have proved robust within much of the comparative social policy literature. It is reasonable to suppose that the same variables that influence the structure of a country's welfare system also influence the structure of its tax system. Therefore, in the comparison of tax ratios and structures we will frequently group countries into these widely used contrasting regimes.

\section{TAX LeVELS}

The most salient feature of a country's tax system is how much revenue it collects. The usual way of comparing how much taxes are collected across countries is to express the taxes collected in a country as a percentage of the size of the economy, the country's gross domestic product (GDP). Table 1 provides this ratio for each OECD-19 country for five-year intervals from 1965 to 2000 and for a six-year interval from 2000 to 2006 (the last year for which official data rather than provisional estimates for all nineteen

8 There is a lively debate in the literature as to whether these Mediterranean countries are rudimentary welfare states that are moving towards their more developed Northern states or in fact represent an entirely separate social contract. See Maurizio Ferrera, The 'Southern Model' of Welfare in Social Europe, 6 J. EuR. SOC. POL'Y 17 (1996); Stephan Leibfried, Towards a European Welfare State?, in NEW PERSPECTIVES ON THE WELFARE STATE IN EUROPE 133 (Catherine Jones ed., 1993).

9 See Families of Nations (Francis Geoffrey Castles ed., 1993); Wil Arts \& John Gelissen, Three Worlds of Welfare Capitalism or More? A State-of-the-Art Report, 12 J. Eur. SOC. POL'Y 137 (2002); Colin Crouch, Models of Capitalism, 10 NEw POL. ECON. 439 (2005); Clare Bambra, Decommodification and the Worlds of Welfare Revisited, 16 J. EUR. SOC. POL'Y 73 (2006); Lyle Scruggs \& James Allan, Welfare-State Decommodification in 18 OECD Countries: A Replication and Revision, 16 J. EUR. SOC. POL'Y 55 (2006); Carsten Jensen, Worlds of Welfare Services and Transfers, 18 J. EuR. SOC. POL'Y 151 (2008).

10 Gregory J. Kasza, The Illusion of Welfare 'Regimes,' 31 J. SOC. POL'Y 271 (2002). 
countries are available from the OECD Revenue Statistics database). The ratio is expressed as an average over multi-year periods since the tax collected in a country as a percentage of GDP in any one year is invariably affected by that part of the business cycle the country is experiencing and other macroeconomic variables.

Aside from its rising trend, what is perhaps most striking about the tax ratio is how widely it varies from country to country. In the six years from 2000 through 2006, the U.S. collected the least amount of taxes among the OECD-19, averaging 27.5 percent of GDP. That is in sharp contrast to the average total tax revenue of 49.3 percent of GDP collected by Sweden, which tops the industrialized countries in tax collection in the period. As a percentage of the size of its economy, Sweden collects almost twice as much in taxes as the U.S. The U.S. is also the only country among the nineteen countries with average total tax revenue of less than 30 percent of GDP. Ten of the countries collected average total tax revenue of more than 30 percent of GDP but less than 40 percent in the period, while the remaining eight collected average total tax revenue of 40 percent of GDP or more. On average, the four countries with the highest levels collected over 50 percent more taxes as a percentage of their GDP than the four lowest-taxed countries in 2000-06.

This wide variation among countries of approximately equal economic development would seem to suggest that countries have a good deal of freedom in determining how they will pursue their national goals. At least up until recent years, countries have functioned with very different tax levels. This large variation in the tax/GDP ratio among industrialized countries also calls into question the straightforward neoclassical economic version of the limits to taxation. From time to time, economists have warned that the marginal deadweight costs of the redistributive state rise nonlinearly and have cautioned that governments could only collect 25 percent (or some relatively low figure) of taxes as a percentage of GDP without doing irreparable economic damage to their national economies. ${ }^{11}$ It seems unlikely that the highest-taxed countries have discovered a formula for raising taxes that allows them to do so without bearing the huge marginal costs that are often predicted to result from raising taxes in the lower-taxed countries. ${ }^{12}$

11 Vito Tanzi \& Ludger Schuknecht, Public Spending in the 20th Century: A Global Perspective 54 (2001).

12 For empirical evidence that high-tax countries appeared to have achieved better social policy outcomes without suffering irreparable economic harm, see NEIL Brooks \& Thaddeus HWong, The Social Benefits and Economic Costs of TAXATION: A COMPARISON OF HIGH- AND LOW-TAX COUNTRIES (2006), available at 
Table 1: Rising Tax Ratios of OECD-19 13

Average Total Tax Revenue as \% of GDP

\begin{tabular}{|c|c|c|c|c|c|c|c|c|c|}
\hline Group & Country & $1965-69$ & $1970-74$ & $1975-79$ & $1980-84$ & $1985-89$ & $1990-94$ & 1995-99 & 2000-06 \\
\hline \multirow{6}{*}{ Nordic } & Sweden & 37.2 & 39.1 & 45.6 & 47.0 & 50.4 & 48.3 & 50.0 & 49.3 \\
\hline & Denmark & 32.0 & 40.6 & 40.2 & 43.2 & 48.2 & 47.0 & 49.3 & 48.9 \\
\hline & Finland & 31.7 & 33.3 & 37.8 & 36.9 & 40.9 & 45.0 & 46.2 & 44.5 \\
\hline & Norway & 32.3 & 37.7 & 40.6 & 42.5 & 42.5 & 40.5 & 41.7 & 43.1 \\
\hline & Average & 33.3 & 37.7 & 41.0 & 42.4 & 45.5 & 45.2 & 46.8 & 46.4 \\
\hline & $\begin{array}{l}\text { Standard } \\
\text { Deviation }\end{array}$ & 2.6 & 3.2 & 3.3 & 4.1 & 4.5 & 3.7 & 3.8 & 3.1 \\
\hline \multirow{7}{*}{$\begin{array}{l}\text { Continental } \\
\text { European }\end{array}$} & Belgium & 33.6 & 35.3 & 41.2 & 42.7 & 43.6 & 42.6 & 44.5 & 44.8 \\
\hline & France & 34.2 & 33.9 & 37.1 & 41.2 & 42.4 & 42.3 & 44.2 & 43.8 \\
\hline & Austria & 34.5 & 34.9 & 37,5 & 39.4 & 40.4 & 40.9 & 43,0 & 43.0 \\
\hline & Netherlands & 34.6 & 38.0 & 41.5 & 42.8 & 43.9 & 44.2 & 40.5 & 38.2 \\
\hline & Germany & 32.4 & 33.4 & 35.9 & 35.8 & 36.1 & 36.4 & 36.7 & 35.6 \\
\hline & Average & 33.9 & 35.1 & 38.6 & 40.4 & 41.3 & 41.3 & 41.8 & 41.1 \\
\hline & $\begin{array}{l}\text { Standard } \\
\text { Deviation }\end{array}$ & 0.8 & 1.6 & 2.3 & 2.6 & 2.9 & 2.6 & 2.9 & 3.5 \\
\hline \multirow{6}{*}{ Mediterranean } & Italy & 26.1 & 25.5 & 26.3 & 32.5 & 35.4 & 39.8 & 41.9 & 41.6 \\
\hline & Spain & 15.6 & 16.8 & 20.1 & 24.6 & 30.2 & 32.9 & 32.9 & 34.8 \\
\hline & Portugal & 16.8 & 18.0 & 21.0 & 24.8 & 26.2 & 29.3 & 32.7 & 34.5 \\
\hline & Greece & 19.6 & 19.3 & 21.1 & 23.7 & 25.6 & 27.0 & 32.0 & 32.3 \\
\hline & Average & 19.5 & 19.9 & 22.1 & 26.4 & 29.3 & 32.3 & 34.9 & 35.8 \\
\hline & $\begin{array}{l}\text { Standard } \\
\text { Deviation }\end{array}$ & 4.7 & 3.9 & 2.8 & 4.1 & 4.5 & 5.6 & 4.7 & 4.0 \\
\hline \multirow{8}{*}{$\begin{array}{l}\text { Anglo- } \\
\text { American }\end{array}$} & U.K. & 33.0 & 34.3 & 34.0 & 37.1 & 37.1 & 34.2 & 35.2 & 36.1 \\
\hline & New Zealand & d 24.6 & 27.0 & 30.2 & 31.2 & 34.2 & 36.3 & 34.6 & 34.9 \\
\hline & Canada & 27.9 & 31.0 & 30.9 & 32.5 & 33.7 & 35.8 & 36.3 & 34.0 \\
\hline & Australia & 20.8 & 22.7 & 25.7 & 27.1 & 28.7 & 27.4 & 29.6 & 30.6 \\
\hline & Ireland & 27.2 & 28.7 & 29.6 & 33.5 & 35.2 & 34.0 & 31.9 & 30.1 \\
\hline & U.S. & 25.8 & 25.9 & 25.7 & 26.0 & 26.1 & 27.2 & 28.7 & 27.5 \\
\hline & Average & 26.5 & 28.3 & 29.4 & 31.2 & 32.5 & 32.5 & 32.7 & 32.2 \\
\hline & $\begin{array}{l}\text { Standard } \\
\text { Deviation }\end{array}$ & 4.0 & 4.1 & 3.2 & 4.1 & 4.2 & 4.1 & 3.1 & 3.3 \\
\hline \multirow{3}{*}{ OECD-19 } & Average & 28.4 & 30.3 & 32.7 & 35.0 & 36.9 & 37.4 & 38.5 & 38.3 \\
\hline & & & & & & & & & \\
\hline & $\begin{array}{l}\text { Standard } \\
\text { Deviation }\end{array}$ & 6.4 & 7.3 & 7.8 & 7.3 & 7.5 & 6.8 & 6.7 & 6.5 \\
\hline
\end{tabular}

Source: OECD.

http://www.policyalternatives.ca/documents/National_Office_Pubs/2006/Benefits_ and_Costs_of_Taxation.pdf.

13 Data from OECD's Revenue Statistics dataset associated with the 2008 edition of Revenue Statistics. See OECD, Revenue Statistics 1965-2007 (2008). Averages of countries were calculated for five-year panels, and the averages were used to calculate country-group averages. Standard deviations were also calculated. 
The table also reveals that although tax levels reflect only one characteristic used by political economists to classify welfare-state regimes, in fact tax levels are a fairly accurate predictor as to which welfare state regime a country belongs. In 2000-06, all the OECD-19 countries except three have average tax/GDP ratios within four percentage points of their respective country group average, and all except one have average tax/GDP ratios within five percentage points of their respective country group average. No country group has a majority of countries with tax/GDP ratios three points or more higher or lower than the group average.

The four Nordic countries have an average tax/GDP ratio of 46.4 percent. The average tax/GDP ratio from 2000-06 in the Continental European countries was 41.1 percent, five percentage points below the Nordic countries. We have classified Italy as a Mediterranean country; however, its tax ratio is equal to the Continental European average. There is some dispute among welfare state analysts as to whether Italy should be classified along with the Continental European countries instead of with the Mediterranean countries.

The average tax/GDP ratio from 2000-06 in the Mediterranean countries was 35.8 percent, over five percentage points below the Continental European countries. Finally, the Anglo-American countries have an average tax ratio over this period of only 32.2 percent.

Confirming the explanatory power of this classification scheme, the between-regime differences in tax levels are notably larger than the within-regime differences involving individual countries. Using the average tax/GDP ratio from 2000-06, the standard deviation of the ratio for all countries is 6.5 percentage points, in comparison to within-regime differences for Nordic, Continental European, Mediterranean, and AngloAmerican of $3.1,3.5,4.0$, and 3.3 percentage points, respectively. Withinregime differences are thus much smaller than between-regime differences.

In terms of the trend in tax levels, the tax ratio in the average OECD-19 country increased from 28.4 percent in $1965-69$ to 38.3 percent in 2000-06, an increase of 35 percent or 10 percentage points. Most of the increase took place in the first half of that period, between 1965-69 and 1985-89 (8.5 percentage points). Nevertheless, the fact that this five-year average tax ratio for the average OECD-19 country has increased from 36.9 percent in 1985-89 to 38.3 percent in 2000-06 has been taken to suggest that globalization has not affected the ability of welfare states to finance government spending programs. However, a number of considerations suggest this conclusion is somewhat misleading.

First, the increase over this last twenty-year period is only 1.4 percentage points, and indeed in the last period (2000-06) the ratio declined by 0.2 percentage point. Second, a good part of the increase in the average is 
due to the growth in tax levels in the Mediterranean countries, where the ratio increased from 29.3 percent to 35.8 percent (6.5 percentage points) during this period. The Mediterranean states started the period at a relatively low level and were clearly simply converging with the rest of Europe. Third, the ratio in the average Anglo-American and Continental European country declined slightly over the past twenty years. Fourth, in terms of the convergence of tax ratios, as Table 1 reveals, the variation of the average tax ratios of the OECD-19 in 2000-06 is little changed from that in 1965-69. The standard deviation of the average tax ratios increased from the mid-1960s until the mid-1980s, hinting at a divergence until that point. However, the standard deviation has decreased since the late 1980 s, hinting at the possibility of convergence. ${ }^{14}$

Although there has been little convergence of tax levels, the fact that the average tax ratio has increased only very slightly over these past twenty years and in the most recent years has declined slightly is likely an indication that countries are constrained by the pressures of globalization. A number of economic, social and political developments over this period should have resulted in expanded welfare state efforts. That is to say, without the constraints imposed by globalization, one would have expected the tax ratio in most industrialized countries to continue to increase.

First, demographic changes, such as changing family status (resulting in fewer individuals being available to perform unpaid care-giving work) and an aging population, should have resulted in greater demands for public services. Second, related to these two demographic changes that would seem to have required greater government-provided services over the past thirty years, the need for increased taxes might also have been expected to become more acute in many countries because of the recognition that greater government services for care-giving work and public services that facilitate a work-family balance are a precondition for functional gender equality. Third, another trend that should have resulted in the need for greater government expenditures over the past thirty years is that in most industrialized countries unemployment was higher over this period than in previous decades. Fourth, over the past thirty years there has also been a sharp rise in inequality, particularly in some Anglo-American countries. One would expect that as inequality increases there would be an increased need to make more use of the tax system to achieve a more socially acceptable post-tax distribution of income. Moreover, as a political

14 The changes in the variation of tax ratios could just be chance occurrences. There is no statistically significant difference between the standard deviation of one period and that of the prior period. 
matter, increased inequality should be expected to increase political pressure for redistribution as the number of voters below the mean increases. Fifth, somewhat paradoxically, globalization itself increases the need for taxation because it increases the instability of economies and the economic insecurity of workers; this in turn should lead to an increased demand for social insurance schemes. A sixth reason why government expenditures (and therefore taxes) might have been expected to constitute an increasing share of GDP over the past thirty years is that GDP per capita has been growing. As people get wealthier, there is no reason to suppose they will continue to spend the same percentage of their income on all goods and services. As people become better off, one would expect them to spend relatively more on those goods and services that they value most such as education, healthcare and insurance against economic insecurity. One might also expect that as people become wealthier, they would devote more of their wealth to assisting those less fortunate than themselves. Thus, since most of these services are provided through government in many countries, increased wealth should result in greater government services and taxes in those countries in which these services are provided primarily through government. Finally, one might have expected taxes to continue increasing over the past thirty years because so many of the services that are purchased through the public sector are heavily labor-intensive, such as defense, law and order, and social, healthcare and educational services. Jobs in these sectors do not experience substantial labor productivity gains. By contrast, in manufacturing and technological jobs there have been astounding productivity gains. Yet, even though there has been little growth in the productivity of the provisions of personal services, generally personal service providers, such as teachers and nurses, must continue to be paid the same relative salaries as paid workers in manufacturing. Therefore, the cost of these services, relative to other goods and services, must continue to increase. Consequently, as personal services continue to become relatively more expensive, citizens must be prepared to spend relatively more each year on government services - taxes have to slowly rise each year - simply to maintain the same level of services. This phenomenon of the increasing relative cost of services in which there is a lack of growth of productivity is frequently referred to as Baumol's cost disease, according to William Baumol's major contribution to its development in his 1967 article Macroeconomics of Unbalanced Growth. ${ }^{15}$

15 William Baumol, Macroeconomics of Unbalanced Growth: The Anatomy of Urban Crisis, 57 Am. ECON. REv. 415 (1967). A recent overview can be found in a paper revisiting the model in the context of health expenditures. See Jochen Hartwig, What Drives Health Care Expenditure? - Baumol's Model of 'Unbalanced Growth' Revisited, 27 J. HEALTH ECON. 603, 605-07 (2008). 
This somewhat cryptic list of factors that might have been expected to put upward pressure on government spending over the past thirty years, and hence to have led to increased tax levels, does not of course prove conclusively that globalization has constrained the ability of governments to tax. Nevertheless, it surely raises that possibility.

\section{Corporate InCome TaXation ${ }^{16}$}

One of the most dramatic changes in tax structures over the past twenty-five years has been the drop of the statutory corporate tax rate. The average statutory corporate tax rate of the OECD-19 countries has fallen from an average of around 50 percent in 1981 to an average of less than 30 percent in 2008 , a decline of over 40 percent. As Figure 1 shows, the rate declined sharply in the late $1980 \mathrm{~s}$, remained steady in the mid-1990s, slipped again in the late $1990 \mathrm{~s}$, and has continued falling over the past eight years. The downward trend shows no signs of abating. Except Norway, all OECD-19 countries have cut their corporate tax rates since 2001. For example, Canada announced in 2007 a series of rate cuts that will reduce the federal corporate tax rate from about 22 percent in that year to 15 percent in 2015. These cuts will bring the combined federal- provincial corporate rate down from about 36 percent in 2007 to 25 percent in $2015 .{ }^{17}$ Germany also cut the overall tax rate for corporations from about 39 percent to 30 percent in $2007 .{ }^{18}$ Italy dropped its rate from 33 to $27.5^{19}$ and the UK reduced its rate from 30 to 28

16 The trends in the corporate tax have been widely explored in both the political science and economics literature. See generally Joel Slemrod, Are Corporate Tax Rates, or Countries, Converging?, 88 J. PuB. ECON. 1169 (2004); Michael P. Devereux, Business Taxation in a Globalized World, 24 OXFORD REV. ECON. POL'Y 625 (2008); Alan Auerbach, Michael P. Devereux \& Helen Simpson, Taxing Corporate Income (Ctr. for Bus. Taxation, Working Paper No. 07/05, 2007); Simon Loretz, Corporate Taxation in the OECD in a Wider Context, 24 OXFORD REV. ECON. POL'Y 639 (2008).

17 GOV'T OF CANADA, DEP'T OF FIN., BUDGET 2008 ch. 3 (2008), available at http:// www.budget.gc.ca/2008/plan/chap3b-eng.asp; GOV'T OF CANADA, DEP'T OF FIN., BUDGET 2009 annex 2 (2009), available at $\mathrm{http}: / / w w w . b u d g e t . g c . c a / 2009 / \mathrm{plan} / \mathrm{bpa2}-$ eng.asp \#2.

18 Wolfgang Kessler \& Rolf Eicke, Germany's Corporate Tax Reform - The Road Not Taken, 46 TAx NOTES INT'L 1107, 1135 (2007).

19 Herman P. Ayayo, Senate Approves 2008 Finance Bill, 49 TAX Notes InT'L 40 (2008). 
in $2008 .^{20}$ Sweden cut its corporate tax rate from 28 percent to 26.3 percent, effective January $2009 .^{21}$

Changes in the corporate statutory rate do not necessarily lead to changes in the amount of corporate taxes paid, as the tax base might be broadened at the same time the rates are being reduced. Two measures that take account of both changes in the statutory rate and changes in the tax base (for example, changes in the rate of depreciation allowed for capital assets, in investment tax credits, in permissible inventory accounting methods, or in withholding taxes on cross-border flows) are frequently used in assessing the effective corporate taxes paid on new investments: the marginal effective tax rate (METR) and the average effective tax rate (AETR). The METR is the proportion of the rate of return on a marginal investment (an investment that breaks even) paid in taxes, taking into account of the statutory tax rate and the major features of the corporate tax base. Hence, it is the rate that a corporation considers when deciding whether to make a new investment. The AETR is the actual tax paid by a corporation divided by some measure of its pretax accounting income. It is the rate of tax a corporation considers when deciding where to locate a new investment. Figure 1 compares the decline in statutory rates across the OECD-19 countries with the declines in these two effective rates. The effective rates have declined less sharply than the statutory rate, indicating that base-broadening measures have made up for some, but certainly not all, of the loss of revenue due to declining statutory rates.

A key question in comparative tax law is what explains this trend of falling statutory corporate tax rates? Is it due to a change in the prevailing ideas about the ideal design of a corporate income tax? Does it reflect the spread of neo-liberal ideology? Have those interests that would gain from reduced rates increased their political power, or have changes in the socioeconomic environment, in particular the pressures created by globalization, dictated the changes? Of course, the trend could be (and likely is) due in part to changes in all of these variables.

20 Bill Dodwell, Debbie Griffiths \& Christopher Maton, UK Budget Delivers Relief for Some, Pain for Others, 49 TAX NOTES INT'L 907 (2008).

21 Randall Jackson, Sweden Announces Corporate, Individual Tax Cuts, 51 TAX NOTES INT'L 984 (2008). 
Figure 1: Falling Corporate Tax Rates $^{22}$

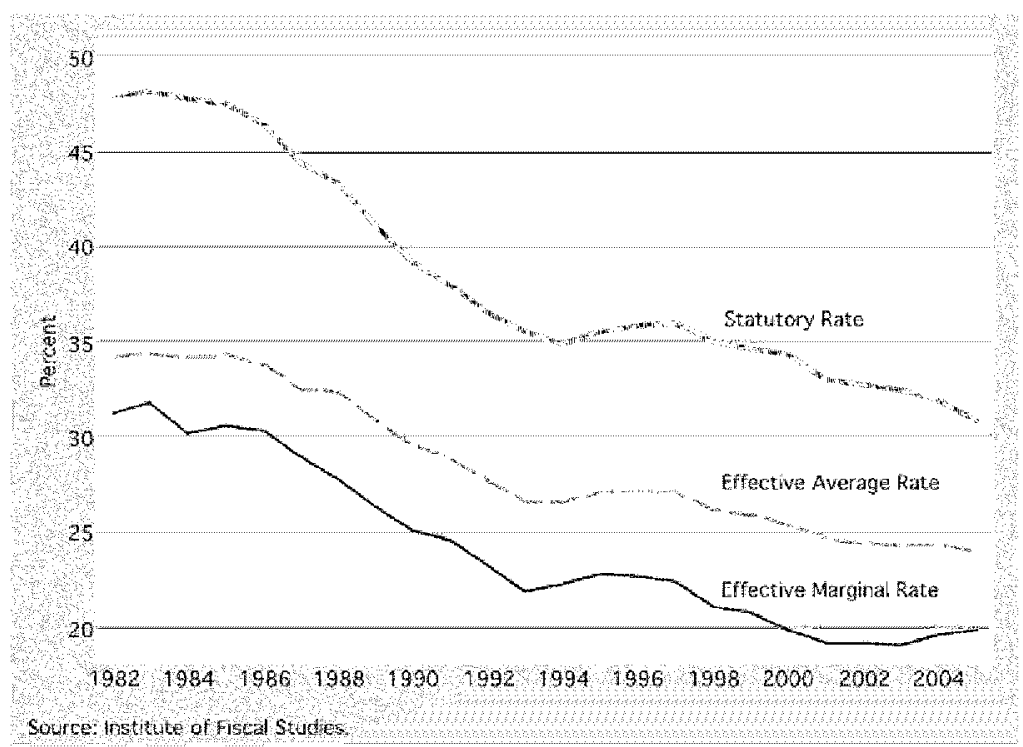

Although a slight downward trend in statutory corporate tax rates appears to have started a few years earlier, the major turning point was undoubtedly the U.S. 1986 Tax Reform Act. Those reforms cut the U.S. tax rate from 46 to 34 percent. This reduced rate was more than compensated by base-broadening measures, and corporate tax revenues actually increased and indeed compensated for some of the revenue losses due to the reduced rates in the personal income tax. Although there are a number of possible explanations for the U.S. change, it undoubtedly reflected, in large part, a fundamental change in ideas about the appropriate design of the corporate tax. Over the previous thirty years, high corporate tax rates were combined with a broad array of corporate tax incentives designed to steer corporate investments into government-favored activities. Following a series of economic studies, corporate tax incentives were widely seen as being ineffective, leading to the misallocation of resources, causing unfairness, and complicating the tax system. ${ }^{23}$ This resulted in pressure to reduce the

22 Time-series data from Institute of Fiscal Studies dataset. See Alexander Klemm, Inst. for Fiscal Studies, Corporate Tax Rate Data (Jan. 2005), http://www.ifs.org.uk/publications/3210.

23 Duane Swank \& Sven Steinmo, The New Political Economy of Taxation in Advanced Capitalist Democracies, 46 AM. J. POL. SCl. 642 (2002); Sven Steinmo, The Evolution of Policy Ideas: Tax Policy in the 20th Century, 5 BRIT. J. POL. \& INT'L REL. 206 (2003). 
corporate tax rate and broaden the tax base. Along with other political factors, this pressure coalesced in the U.S. to produce the 1986 Tax Reform Act.

Legislators in other countries were undoubtedly influenced by the same ideas that persuaded those in the U.S. Congress that a broad corporate tax base and low rates represented sensible tax policy; however, once the U.S. reduced its corporate tax rates, its major trading partners had little choice but to reduce their rates as well because it was such a dominant capital-exporting country at that time. The reason for this is that U.S. multinationals receive a foreign tax credit for income taxes paid in foreign countries when they repatriate their foreign earnings, but only up to the tax that would be paid on that income if it had been earned in the U.S. Thus, if the foreign tax rates were higher than the U.S. rates, U.S. multinationals would not receive a full credit in the U.S. for those taxes. Hence, Canada and other countries almost immediately followed the U.S. reforms and reduced their corporate tax rates. ${ }^{24}$

Although the U.S. changes might have started the trend of falling statutory corporate rates, countries soon began reducing their rates far below the prevailing U.S. rate. There are two well-known reasons why countries have to be concerned about the corporate tax rates imposed by other countries and compete with them in reducing their rates. First, by changing their financial structures (for instance, by locating debt and interest expenses in high-tax countries) and by manipulating the prices charged for goods and services transferred between related entities, multinationals have a good deal of discretion as to in which of the countries where they carry on business they report their worldwide profits. Second, the tax rates in a country determine, at least in part, where multinationals locate their plant and equipment. With globalization, it is argued that both decisions became increasingly sensitive to tax rates. ${ }^{25}$ It is difficult to disentangle the effect of changing ideas about the corporate tax, the rise of neo-liberalism, the increasing power of business on statutory corporate tax rates, and the effect of tax competition due to the changing socioeconomic forces of globalization on statutory corporate tax rates; however, there is at least some evidence that tax competition is the dominant explanation for the decline in statutory corporate tax rates.

24 See John Whalley, Foreign Responses to the US Tax Reforms, in DO TAXES MATTER? THE IMPACT OF THE TAX REFORM ACT OF 1986, at 286 (Joel Slemrod ed., 1990); Roger Gordon, Can Capital Taxes Survive in Open Economies?, 47 J. Fin. 1159 (1992).

25 For a recent meta-analysis of the studies, see Ruud De Mooij \& Sjef Ederveen, Corporate Tax Elasticities: A Reader's Guide to Empirical Findings, 24 OXFORD REV. ECON. POL'y 680 (2008). 
Table 2: Changes in Statutory Corporate Income Tax Rates, 1981-2008 ${ }^{26}$

\begin{tabular}{|c|c|c|c|c|}
\hline & & Corporate Inc & Tax Rates (\%) & $\begin{array}{c}\text { Change in } \\
\text { Percentage Points }\end{array}$ \\
\hline & Country & 1981 & 2008 & $1981-2008$ \\
\hline & Finland & 61.5 & 26.0 & -35.5 \\
\hline & Sweden & 57.8 & 28.0 & -29.8 \\
\hline Nordic & Norway & 50.8 & 28.0 & -22.8 \\
\hline & Denmark & 40.0 & 25.0 & -15.0 \\
\hline & Average & 52.5 & 26.8 & -25.8 \\
\hline & Austria & 55.0 & 25.0 & -30.0 \\
\hline & Germany & 60.0 & 30.2 & -29.8 \\
\hline Continential & Netherlands & 48.0 & 25.5 & -22.5 \\
\hline European & France & 50.0 & 34.4 & -15.6 \\
\hline & Belgium & 48.0 & 34.0 & -14.0 \\
\hline & Average & 52.2 & 29.8 & -22.4 \\
\hline & Portugal & 49.0 & 26.5 & -22.5 \\
\hline & Greece & 45.0 & 25.0 & -20.0 \\
\hline Mediterranean & Italy & 36.3 & 27.5 & -8.8 \\
\hline & Spain & 33.0 & 30.0 & -3.0 \\
\hline & Average & 40.8 & 27.3 & -13.6 \\
\hline & Ireland & 50.0 & 12.5 & -37.5 \\
\hline & U.K. & 52.0 & 28.0 & -24.0 \\
\hline & Canada & 51.8 & 33.5 & -18.3 \\
\hline Anglo-American & Australia & 46.0 & 30.0 & -16.0 \\
\hline & New Zealand & 45.0 & 30.0 & -15.0 \\
\hline & U.S. & 49.7 & 39.3 & -10.4 \\
\hline & Average & $49.1 / 48.9^{*}$ & $28.9 / 32.2 *$ & $-20.2 /-16.7^{*}$ \\
\hline OECD-19 & Average & 48.9 & 28.3 & -21.2 \\
\hline
\end{tabular}

First, as Table 2 indicates, the decline in corporate tax rates occurred across all types of welfare-state regimes. Indeed, somewhat surprisingly, the Nordic countries have had the sharpest decline. In 1981 the Nordic countries had the highest average statutory corporate tax rate of 52.5 percent, but in 2008 they had the lowest of 26.8 percent, a rate cut of about 50 percent. If

26 Data and calculations based on OECD Tax Database. See OECD Tax Database, Taxation of Corporation and Capital Income, http://www.oecd.org/document/60 10,3343,en_2649_34533_1942460_1_1_1_1,00.html\#cci (last visited May 16, 2009). 
Ireland is excluded (since it reduced its corporate tax rate to a notoriously low 10 percent on manufacturing firms in 1981, before raising it to only 12.5 percent in 2003 for all corporate business income), the Anglo-American countries had the highest average corporate tax rate of 32.2 percent in 2008 . Changes of the rates in countries within the two country groups are more similar to each other than other groups. In the Nordic group, the range of rate cuts is about 10 percentage points, while in the Anglo-American group the range is about 14 percentage points if Ireland is excluded. The Mediterranean and Continental European groups have wider ranges of rate cuts of 19 and 16 percentage points, respectively. Thus, there is no evidence supporting a linkage between the political leanings of welfare state groups and corporate tax rates.

Second, countries have been reducing their corporate statutory rates in a series of steps. A few countries will reduce their rates and then others will leapfrog over them, reducing their rates slightly more. This series of steps, and the fact that at any given time most countries have reduced their rates to about the same level, suggest they are largely reacting to the changes made by one another.

Third, on the assumption that the economic case for lower corporate tax would be seen to apply as well to lower personal income tax rates, then one might expect the tax rates on corporate income and personal income to fall at the same time. As shown in Table 3, both the top statutory personal rates and the corporate tax rates in the OECD-19 countries have fallen over the last twenty-five years. The personal rate fell from almost 70 percent in 1980 to 47 percent in 2006, while the corporate rate fell from almost 50 percent to about 30 percent over the same period. However, while the top personal income tax rate fell quite dramatically in the late $1980 \mathrm{~s}$ - at about the same time as the first fall in the corporate tax rate — after 1990 the top personal rate fell only slightly, while the corporate tax rate continued to drop dramatically. Since 2000 the personal rate has dropped only 4 percent, while the corporate rate has fallen by 13 percent. The gap between personal and corporate rates narrowed in the 1990s, but has widened again since 2000 and returned closer to its pre-1990 level. ${ }^{27}$ Arguably this suggests that something other than a general aversion to high tax rates was driving the reductions in the corporate tax rate.

Fourth, if tax competition accounted for the reduction in the statutory corporate tax rate, then one would expect the rate to drop faster in

27 Using his time-series data, Loretz made the point about a similar pattern in the gap between personal and corporate rates. See Loretz, supra note 16, at 649. 
Table 3: Comparing Statutory Personal Tax Rate and Statutory Corporate Tax Rate of OECD-19 ${ }^{28}$

\begin{tabular}{cccc} 
Year & $\begin{array}{c}\text { Personal Income Tax } \\
\text { Rate (\%) }\end{array}$ & $\begin{array}{c}\text { Corporate Income Tax } \\
\text { Rate (\%) }\end{array}$ & $\begin{array}{c}\text { Difference in Percentage } \\
\text { Points }\end{array}$ \\
\hline $\mathbf{1 9 8 0}$ & 68.8 & 48.6 & 20.2 \\
$\mathbf{1 9 8 5}$ & 65.8 & 49.5 & 16.3 \\
$\mathbf{1 9 9 0}$ & 53.7 & 41.6 & 12.1 \\
$\mathbf{1 9 9 5}$ & 50.8 & 37.0 & 13.8 \\
& & & \\
$\mathbf{2 0 0 0}$ & 49.1 & 35.1 & 14.0 \\
$\mathbf{2 0 0 1}$ & 48.5 & 33.5 & 15.0 \\
$\mathbf{2 0 0 2}$ & 48.2 & 32.8 & 15.4 \\
$\mathbf{2 0 0 3}$ & 47.8 & 32.2 & 15.6 \\
$\mathbf{2 0 0 4}$ & 47.5 & 31.8 & 15.8 \\
$\mathbf{2 0 0 5}$ & 46.8 & 30.7 & 16.2 \\
$\mathbf{2 0 0 6}$ & 47.0 & 30.4 & 16.6
\end{tabular}

Sources: OECD for all rates except personal income tax rates in 1980, 1990 and 1995 from Fraser Institute.

small countries than in large countries since they are more vulnerable to competitive forces. This appears to be the case. Ganghof finds a significant correlation between country size, as measured by population, and the decline in corporate tax rates. ${ }^{29}$ The relationship has existed since the early $1990 \mathrm{ss}^{30}$

Fifth, and related to country size, a country with a more open economy should experience the pressures of globalization more than a country with a less open economy. There is statistical evidence showing that countries with

28 Data from OECD Tax Database and Fraser Institute. For OECD data, see OECD Tax Database, http://www.oecd.org/document/60/0,3343,en_2649_34533_1942460 1_1_1_1,00.html (last visited May 16, 2009). For Fraser Institute data used, See JAMES D. GWARTNEY \& ROBERT LAWSON WiTH WALTER PARK \& ChaRLES SKIPTON, ECONOMIC FREEDOM OF THE WORLD 2001 ANNUAL REPORT ch. 5 (2001), http://oldfraser.lexi.net/publications/books/efw_2001/(Country Tables).

29 Steffen Ganghof, Globalization, Tax Reform Ideals and Social Policy Financing, 5 GLOBAL SOC. POL'y 77, 84-85 (2005).

30 Ganghof used 2003 data in his analysis. To affirm his findings, bivariate regressions using natural $\log$ of population of one-year lag to explain statutory corporate income tax rates of OECD-19 of each year in 1981-2005 were run. They show that 1993 is the turning point. Since 1993, R-squared has been 0.27 or higher, and population has become statistically significant at the five-percent level. Prior to 1993, the regressions do not find a statistically significant relationship between population and statutory income tax rates. 
a larger sum of inflow and outflow of foreign direct investment tend to have lower statutory corporate income tax rates. ${ }^{31}$

Statutory rates continue to fall across the OECD-19 countries and, even without further increases in the mobility of financial capital and plant and equipment and further ease in manipulating accounting profits, there is no reason to believe that an equilibrium level has been reached.

Paradoxically, although there have been dramatic reductions in the statutory corporate tax rates and in average effective tax rates, in most countries there has been no decline in the amount of revenue collected from corporate income taxes, whether measured as a percentage of GDP or of the total tax collected. Indeed, as Figure 2 indicates, corporate tax revenues have been increasing both as a percentage of GDP and as a percentage of total tax revenue. This has led some to suggest that the effect of tax competition on corporate taxes has been exaggerated. However, there are a number of explanations for the fact that corporate tax revenues have not declined even though corporate tax competition has led to a decline in statutory corporate tax rates.

The most obvious explanation for the maintenance of corporate tax revenues in the face of declining statutory rates is that the corporate tax base has been expanded to make up for the lost revenue. To some extent that is the case, but it does not account for even most of the additional collected revenues. As Figure 1 shows, effective tax rates, which account for rate reductions and base-broadening, have been declining, although not at as fast as the statutory rate - thus some base-broadening has obviously taken place. There are other explanations for the recent robustness of corporate tax revenues; however, that does not bode so well for the long-term viability of the tax.

One important reason why corporate tax revenues have increased even though rates have been reduced is that corporate tax profits as a share of GDP have increased greatly over the past twenty or so years. In many countries, in fact, corporate profits as a percentage of GDP had reached historically unprecedented levels just before the worldwide economic meltdown. In part, this higher profit share, and thus higher corporate tax revenues, has been attributed to the liberalizing forces of globalization. ${ }^{32}$ Also, Devereux

31 Regressing the natural log of total foreign direct investment with a one-year lag as an independent variable against statutory corporate tax rates as the dependent variable in 1991-2005 shows that the coefficient is negative and statistically significant at a five-percent level. Data used in calculations were taken from OECD datasets. Foreign direct investment (FDI) data were from OECD Factbook dataset. For information, see, OECD, OECD FACTBOOK 2009: ECONOMIC, ENVIRONMENTAL AND SOCIAL STATISTICS (2009). For corporate tax rates, see OECD Tax Database, supra note 28.

32 Johannes Becker \& Clemens Fuest, Internationalization and Business Tax Revenue 
et al. have suggested that another potential explanation for the growing share of corporate profits in the economy is the rising share of the highly profitable financial sector in the economy. ${ }^{33}$

\section{Figure 2: Trends of Corporate Tax as Percent of GDP and Total Tax Revenue, 1981-2005 ${ }^{34}$}

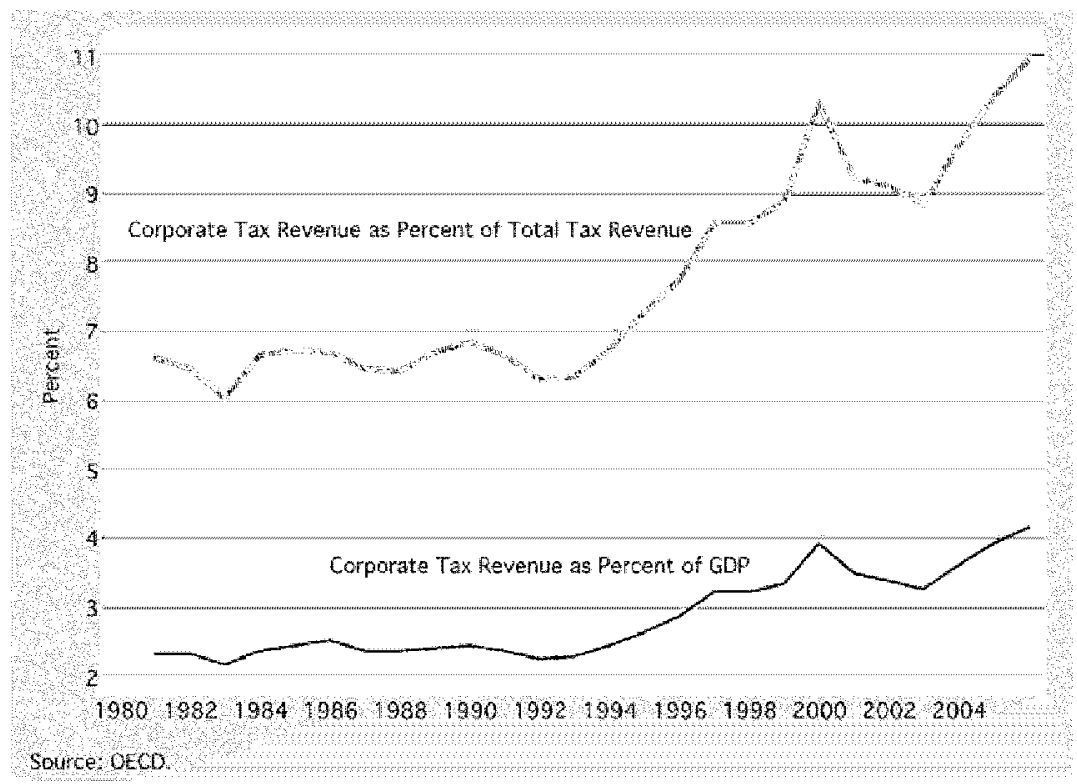

Another reason why corporate tax revenues have increased is that the gap between the top personal marginal tax rate and the corporate tax rate has widened, creating an increased incentive to shift income from the personal to the corporate sector. This shift might be due to the increased incorporation of business activity, the transfer of portfolio investments into corporations, or the transformation of labor income into business income earned in corporations by, for example, controlling shareholders simply reducing salary withdrawals. Mooij and Nicodème have recently estimated

- Evidence from Germany (July 12, 2007) (paper prepared for the ETPF meeting in London, Apr. 23, 2007), available at http://www.etpf.org/papers/24international.pdf.

33 Michael P. Devereux, Rachel Griffith \& Alexander Klemm, Why Has the UK Corporate Tax Raised So Much Revenue (Inst. Fiscal Stud., Working Paper No. W04/04, 2004).

34 Time-series data from OECD's Revenue Statistics dataset. See OECD, supra note 13. 
that as high as over 20 percent of annual corporate tax revenue can be explained by the shift in the tax base from relatively higher-taxed personal income to lower-taxed corporate income. ${ }^{35}$

Competition between countries over statutory corporate tax rates is troubling in its own right since it limits the ability of governments to raise revenue from the corporate sector, distorts the location of business plant and equipment, and results in wasteful efforts to shift corporate profits to low-tax countries. However, it has more subtle adverse effects on tax structures. First, it results in the shifting of taxes from highly profitable multinational corporations that earn economic rents to small and medium-sized, often domestically owned businesses. ${ }^{36}$ Second, it shifts taxes from capital to consumption and labor. Third, it undermines the progressivity of the personal income tax when the corporate tax rate is reduced it places pressure on the top personal marginal tax rate as individuals attempt to transform personal income into corporate source income. Fourth, it results, in particular, in a substantial decline in tax revenues for those countries that are unable to broaden their corporate tax bases to recoup the revenue loss. This is particularly a problem for low-income countries since they tend to rely heavier on the corporate tax for general revenues than high-income countries, and since for a number of reasons they often have difficulty broadening their corporate tax bases in order to make up the revenue lost through rate reductions. ${ }^{37}$

\section{Vi. Personal Incone Taxation}

Like statutory corporate tax rates, personal statutory tax rates have declined dramatically over the past thirty years or so. Following World War II, top marginal rates soared in some countries, for example, to in excess of 90

35 Ruud de Mooij \& Gaëtan Nicodème, How Corporate Tax Competition Reduces Personal Tax Revenues, 2008 CESIFo DICE RePORT 27; Ruud De Mooij \& Gaëtan Nicodème, Corporate Tax Policy, and Incorporation in the EU, 15 INT'L TAX \& PUB. Fin. 478, 494-95 (2008).

36 Michael P. Devereux, Rachel Griffith, \& Alexander Klemm, Corporate Income Tax Reforms and International Tax Competition, 17 ECON. POL'Y 451 (2002).

37 Michael Keen \& Alejandro Simone, Is Tax Competition Harming Developing Countries More Than Developed?, 34 TAX NOTES INT'L 1317 (2008) (on average, corporate tax revenues made up 17 percent of total revenues in developing countries, compared to only 7 percent in developed countries, and between 1990 to 2001 corporate tax revenues declined on average by about 20 percent in developing countries due to rate reductions and their inability to make up the revenue through base-broadening). 
percent in the U.S. During the 1950s and 1960s, the top rate in many countries exceeded 80 percent. As late as 1980, as Table 3 shows, the top rate in the average OECD-19 country was only slightly less than 70 percent; by 1990 it had declined to about 54 percent, and by 2000 to about 49 percent. As Table 4 shows, over the past seven years the top personal rate dropped further, almost three percentage points, to 46.4 percent. It has declined in each welfare state regime. In 2007, the Nordic countries had the highest average top marginal personal tax rate of 51.7 percent, while the Anglo-American countries had the lowest at 42.4 percent.

Again, like the decline in the statutory corporate tax rate, the decline in the personal rate is likely due to a number of factors: changing ideas about the tradeoff between equity and efficiency; the influence of neo-liberalism; and attempts by countries to create a friendly labor market environment for high-income individuals and to signal a business-friendly environment. However, Ganghof and others have argued that, at least after the U.S. tax reforms of 1986, the downward trend in the personal top income tax rate is in part the result of a spillover effect caused by the reduction in the statutory corporate tax rate (which in turn was due in large part to international competitive pressures caused by globalization). ${ }^{38}$ As the corporate tax rates were reduced, countries felt obliged to reduce the top personal rate in order to reduce the gap between the two rates. A large gap between the corporate and personal tax rates provides a strong incentive for individuals to seek ways of sheltering their personal income from the top personal rate by shifting into corporate forms. Although anti-avoidance measures can prevent this shift to some extent, most countries have felt the need to reduce the incentive for such tax planning by keeping the gap within reasonable bounds. Ganghof argues that this spillover effect has been mediated by domestic factors, such as partisan ideology and veto points in the legislative process, leading to the fairly large difference in the top rates between the Nordic and the AngloAmerican countries. ${ }^{39}$ Nevertheless, all welfare state regimes have felt the need to respond to international tax competition.

In the average OECD-19 country, revenues from the personal income tax have fallen both as a percentage of GDP, from 11.4 percent in $1980-84$ to 10.9 percent in $2000-06$, and as a percentage of total tax revenues, from 31.9 percent in $1980-84$ to 28.3 percent in $2000-06$.

38 StefFEn Ganghof, The Politics of InCOME TAXation: A COMPARATIVE ANALYSiS 37-41 (2006) [hereinafter GANGHOF, POLITICS OF InCOME TAXATION]; Steffen Ganghof \& Philipp Genschel, Taxation and Democracy in the EU, 15 J. EUR. PUB. POL'y 145 (2008).

39 Ganghof, Politics of Income Taxation, supra note 38, at 43-58. 
Table 4: Top Statutory Personal Income Tax Rate, 2000-07 $7^{40}$

\begin{tabular}{|c|c|c|c|c|c|c|c|c|c|}
\hline & & \multicolumn{8}{|c|}{ Top Statutory Personal Income Tax Rate (\%) } \\
\hline & & 2000 & 2001 & 2002 & 2003 & 2004 & 2005 & 2006 & 2007 \\
\hline \multirow{5}{*}{ Nordic } & Denmark & 59.7 & 59.7 & 54.4 & 59.7 & 59.7 & 59.7 & 59.7 & 59.7 \\
\hline & Sweden & 55.4 & 55.5 & 55.5 & 56.2 & 56.5 & 51.6 & 56.6 & 56.5 \\
\hline & Finland & 55.2 & 54.7 & 53.8 & 53.0 & 52.1 & 51.8 & 50.9 & 50.5 \\
\hline & Norway & 47.5 & 47.5 & 47.5 & 47.5 & 47.5 & 43.5 & 40.0 & 40.0 \\
\hline & Average & 54.4 & 54.4 & 52.8 & 54.1 & 54.0 & 51.7 & 51.8 & 51.7 \\
\hline \multirow{6}{*}{$\begin{array}{l}\text { Continental } \\
\text { European }\end{array}$} & Belgium & 63.9 & 63.3 & 55.6 & 53.5 & 53.5 & 53.5 & 53.5 & 53.5 \\
\hline & Netherlands & 60.0 & 52.0 & 52.0 & 52.0 & 52.0 & 52.0 & 52.0 & 52.0 \\
\hline & Austria & 45.0 & 45.5 & 50.0 & 50.0 & 50.0 & 50.0 & 50.0 & 50.0 \\
\hline & France & 53.3 & 53.2 & 60.4 & 57.2 & 55.7 & 55.9 & 55.9 & 47.8 \\
\hline & Germany & 53.8 & 51.2 & 51.2 & 51.2 & 47.5 & 45.2 & 45.4 & 47.5 \\
\hline & Average & 55.2 & 53.0 & 53.8 & 52.8 & 51.7 & 51.3 & 51.3 & 50.1 \\
\hline \multirow{5}{*}{ Mediterranean } & Italy & 46.4 & 45.9 & 46.1 & 46.1 & 46.1 & 44.1 & 44.6 & 44.9 \\
\hline & Spain & 48.0 & 48.0 & 48.0 & 45.0 & 45.0 & 45.0 & 45.0 & 43.0 \\
\hline & Portugal & 35.0 & 40.0 & 40.0 & 40.0 & 40.0 & 40.0 & 42.0 & 42.0 \\
\hline & Greece & 45.0 & 42.5 & 40.0 & 40.0 & 40.0 & 40.0 & 40.0 & 40.0 \\
\hline & Average & 43.6 & 44.1 & 43.5 & 42.8 & 42.8 & 42.3 & 42.9 & 42.5 \\
\hline \multirow{7}{*}{$\begin{array}{l}\text { Anglo- } \\
\text { American }\end{array}$} & Australia & 48.5 & 48.5 & 48.5 & 48.5 & 48.5 & 48.5 & 48.5 & 46.5 \\
\hline & Canada & 46.4 & 46.4 & 46.4 & 46.4 & 46.4 & 46.4 & 46.4 & 46.4 \\
\hline & U.S. & 46.7 & 46.1 & 45.3 & 41.6 & 41.5 & 41.4 & 41.4 & 41.4 \\
\hline & Ireland & 44.0 & 42.0 & 42.0 & 42.0 & 42.0 & 42.0 & 42.0 & 41.0 \\
\hline & U.K. & 40.0 & 40.0 & 40.0 & 40.0 & 40.0 & 40.0 & 40.0 & 40.0 \\
\hline & New Zealand & 39.0 & 39.0 & 39.0 & 39.0 & 39.0 & 39.0 & 39.0 & 39.0 \\
\hline & Average & 44.1 & 43.7 & 43.5 & 42.9 & 42.9 & 42.9 & 42.9 & 42.4 \\
\hline OECD-19 & Average & 49.1 & 48.5 & 48.2 & 47.8 & 47.5 & 46.8 & 47.0 & 46.4 \\
\hline
\end{tabular}

Source: OECD Tax Datahase.

40 Data from OECD Tax Database. For Personal income tax rates, see OECD Tax Database, Personal Income Tax Rates, http://www.oecd.org/document/60/0,3343, en_2649_34533_1942460_1_1_1_1,00.html\#pir (last visited May 16, 2009). 


\section{Consumption Taxes}

Another major trend in tax structures has been the increasing reliance on consumption taxes. The spread of the value-added-tax (VAT) over the past forty years is legendary and has spawned a literature on its own. ${ }^{41}$ But more generally, as a percentage of GDP, general consumption taxes have gone from 5 to 7 percent in the average OECD-19 country from 1980-84 to 2000-06. As a percentage of tax revenue, they have gone from 15 to 18.3 percent over the same period. As Table 5 shows, both as a percentage of GDP and as a percentage of total tax revenue, they have gone up in almost every welfare state regime, except as a percentage of total tax revenue in the Continental European group, which shows a slight slippage.

Table 5: General Consumption Tax Trends ${ }^{42}$

General Consumption Taxes

$1965-691970-741975-791980-841985-891990-941995-992000-06$

\begin{tabular}{|c|c|c|c|c|c|c|c|c|c|}
\hline & OECD-19 & 4.1 & 4.7 & 5.0 & 5.4 & 6.2 & 6.5 & 6.8 & 7.0 \\
\hline Avenage Tax & Nordic & 5.4 & 6.8 & 7.0 & 7.5 & 8.2 & 8.2 & 8.9 & 8.8 \\
\hline \multirow[t]{4}{*}{$\begin{array}{l}\text { Revenue as } \\
\% \text { of GDP }\end{array}$} & $\begin{array}{l}\text { Continental } \\
\text { European }\end{array}$ & 6.3 & 6.7 & 6.9 & 7.3 & 7.3 & 7.1 & 7.2 & 7.2 \\
\hline & Mediterranean & 2.6 & 3.0 & 3.3 & 3.7 & 5.2 & 5.9 & 6.3 & 6.9 \\
\hline & Anglo-American & 2.2 & 2.8 & 3.0 & 3.7 & 4.7 & 5.2 & 5.3 & 5.7 \\
\hline & OECD-19 & 13.8 & 15.1 & 14.7 & 15.0 & 16.7 & 17.2 & 17.5 & 18.3 \\
\hline Average Tax & Nordic & 16.4 & 18.1 & 17.2 & 17.7 & 18.2 & 18.3 & 19.1 & 19.0 \\
\hline Revenue as & Continental & & & & & & & & \\
\hline$\%$ of Total & European & 18.7 & 19.1 & 18.0 & 18.1 & 17.7 & 17.2 & 17.3 & 17.7 \\
\hline $\operatorname{Tax}$ & Mediterranean & 13.7 & 15.1 & 15.0 & 13.9 & 18.2 & 18.9 & 18.6 & 19.7 \\
\hline Revenue & Anglo-American & 8.3 & 9.7 & 10.1 & 11.5 & 13.9 & 15.4 & 15.9 & 17.3 \\
\hline
\end{tabular}

Source: OECD Revenue Statistics.

41 For a discussion of some of this literature, see Kathryn James, An Examination of Convergence and Resistance in Global Tax Reform Trends, 11 THEORETICAL INQUIRIES L. 475 (2010).

42 Data from OECD Revenue Statistics dataset. For information on Revenue Statistics see OECD, supra note 13. 


\section{Why Do We Care About These Trends in Tax Structures?}

These changes in tax structures - lower corporate statutory rates, lower top rates on personal income, and a shift away from taxing income from capital to taxing consumption — are generally applauded by those who are concerned about the effect of taxes on economic efficiency, and they usually attribute the shift in large part to the dictates of tax competition. However, somewhat interestingly, even some commentators who generally see a large role for the government in providing public goods and in attempting to achieve a more socially acceptable distribution of income than that which results from market forces are untroubled by this change in tax structures. In recent years, a number of authors have advanced the view that a regressive tax mix - high revenue shares of consumption and payroll taxes coupled with low rates of tax on income from capital - has been conducive to building and maintaining large welfare states. This argument has been advanced most vigorously by Junko Kato in her book-length study Regressive Taxation and the Welfare State ${ }^{43}$ and by Peter Lindert in his efforts to explain why the welfare state looks like a "free lunch." ${ }^{44}$ Kato's general claim is that "a revenue shift to regressive taxes makes it politically easier to maintain a large public sector" 45 and that in Europe "a mature welfare state is closely connected to a large reliance on regressive taxation."46

Peter Lindert, an economic historian, suggests that the Nordic welfare states enjoy a "free lunch" in the sense that they have delivered much better social outcomes — such as less poverty and more equality - than Anglo-American countries at essentially no cost in terms of GDP. ${ }^{47}$ How have they been able to maintain the high tax levels (about 50 percent of GDP) needed to finance their social insurance programs without imposing large costs on their economies? One of his main conclusions as to why these welfare states have not damaged economic growth is that "they have a more pro-growth and regressive mix of taxes." In particular, "they do not have higher average rates

43 Junko Kato, Regressive Taxation and the Welfare State (2003).

44 Peter H. Lindert, Why the Welfare State Looks Like a Free Lunch (Nat'l Bureau of Econ. Research, Working Paper No. 9869, 2003); PETER H. LINDERT, GROWING Public: Social Spending and ECONOMic Growth Since the Eighteenth Century (2004) [hereinafter Lindert, Growing Public].

45 KATO, supra note 43 , at 51.

$46 I d$. at 112.

47 LinderT, GROWING PuBlic, supra note 44, at 29 ("Conclusion \#7: The net national costs of social transfers, and of the taxes that finance them, are essentially zero. They do not bring the GDP costs that much of Anglo-American literature has imagined."). 
of taxation on capital income." Instead, "they rely more heavily on labor income taxes and on flat consumption (or value added) taxes." 48 Figure 3 illustrates the familiar findings upon which these studies in part are based. Those countries that have high public social expenditures also tend to have tax systems that impose high implicit tax rates on labor and consumption and relatively lesser tax rates on income from capital.

Figure 3: Public Social Expenditures v. Effective Tax Rates ${ }^{49}$

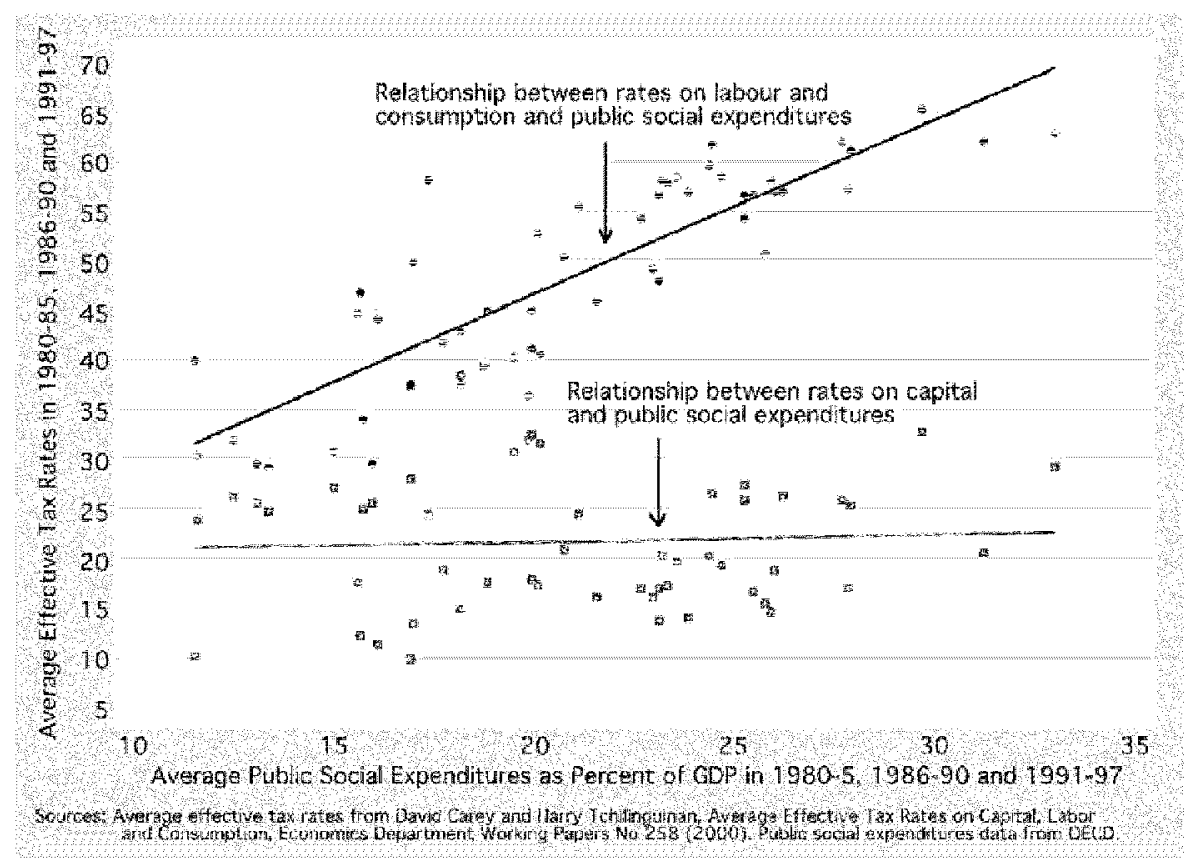

$48 I d$. at 31 . The author also notes that "[t]hey also tax addiction goods (e.g., alcohol and tobacco) more heavily, thus taxing complements to health-compromising leisure." He concludes that "their attention to the side-effects of economic growth seems to have led them to choose types of taxes that minimise or eliminate any damage to growth, relative to the types of taxes levied in lower-spending countries such as the United States, Japan, or Switzerland." Id.

49 For average tax rates, see David Carey \& Harry Tchilinguirian, Average Effective Tax Rates on Capital, Labor and Consumption (OECD Econ. Dep't, Working Paper No. 258,2000 ). For information on OECD social expenditures dataset, see OECD, Social Expenditure Database, http://www.oecd.org/document/9/0,3343,en_2649_ 34637_38141385_1_1_1_1,00.html (last visited May 16, 2009). 
There are a number of possible explanations for the curious fact that countries with high public social expenditures tend to have lower effective rates of tax on income from capital than on income from labor. First, it could reflect an implicit or explicit political bargain struck between groups representing capital and those representing labor and allied groups; the former are prepared to endure high taxes and social transfers while, in return, the latter are prepared to tolerate low taxes on capital. ${ }^{50}$ Second, as suggested by Peter Lindert above, the low rate of tax on capital might reflect a deliberate policy judgment to reduce the taxation of investment in order to encourage economic growth. Third, tax analysts who support consumption taxes have offered a number of tax policy reasons why income from capital should be taxed less than income from labor. ${ }^{51}$ For whatever reasons, these arguments have perhaps had more force in the Nordic countries. Fourth, low rates of tax on income from capital in these countries, which are mainly open economies, might be a consequence of international tax competition. Regardless of the political or policy preferences of the citizens of a country, low rates of tax on capital might be perceived as necessary in order to attract capital and prevent capital flight. Finally, for a host of political reasons, including their higher visibility, taxes on capital might be more difficult to impose than taxes on labor.

Moreover, in reply to those who argue that if too large a share of tax revenues is in the form of regressive taxes the tax system cannot be used as an effective instrument to redistribute income, a number of commentators have pointed out that most countries achieve inequality reduction primarily through the transfer side of their budgets. ${ }^{52}$ If the amount of fiscal redistribution is measured by focusing on the absolute change in the Gini coefficient of inequality before and after government taxes and transfers, across thirteen major industrialist countries on average about 25 percent of the change is accounted for by taxes and 75 percent by transfers. ${ }^{53}$ Moreover,

50 See Sven Steinmo, Globalization and Taxation: Challenges to the Swedish Welfare State, 35 COMP. POL. STUD. 839, 843 (2002) ("The postwar compromise in Sweden can be represented as a 'deal' between labor, capital, and the Social Democratic government in which . . . the Socialists and their labor union allies would conduct wage strategies and tax policies would explicitly favor corporate capital.").

51 These arguments are critically reviewed in Neil Brooks, An Overview of the Role of the VAT, Fundamental Tax Reform and a Defence of the Income Tax, in GST IN RETROSPECT AND PROSPECT 597 (Richard Krever \& David White eds., 2007).

52 See, e.g., LANE KENWORTHY, JOBS WITH EQUALITY 173-98 (2008).

53 The countries are Australia, Belgium, Canada, Denmark, Finland, France, Germany, Netherlands, Norway, Sweden, Switzerland, the UK and the United States. See Vincent A. Mahler \& David K. Jesuit, Fiscal Redistribution in the Developed 
the proportion of the change due to transfers is generally higher in more egalitarian countries. For example, in Sweden, where the total change in the Gini coefficient due to fiscal redistribution was on average 0.218 in recent years, taxes accounted for only about 18 percent of the fiscal redistribution; whereas in the U.S., where the total change in the Gini coefficient due to fiscal redistribution was only 0.102 , taxes accounted for about 45 percent of the change. ${ }^{54}$ Of course, in part, the U.S. tax system plays a larger relative role in redistribution because transfers are so low in that country and do little to redistribute income; nevertheless, the fact that transfers can be relatively effective at reducing inequalities has led some commentators to suggest that progressive taxes are not needed for achieving a more equal society. ${ }^{55}$

It is the case that if the only purpose of taxes were to finance redistributive transfer payments the tax rate could be flat. However, if there is a case for redistributing from the very rich, because they have no moral claim to their vast incomes or because their economic power threatens democratic values and the quality of life in a society, then transfer payments cannot, obviously, be used for this purpose.

There is evidence to suggest that the Nordic dual income tax rates, in which income from capital is taxed at a low flat rate, have resulted in much greater inequality at the top end of the income scale. In Finland, after years of declining inequality, beginning in the mid-1990s there was an unprecedented surge in the share of income received by the top one percent. Unlike Anglo-American countries, where the recent increase in inequality was due largely to the large salaries received by high-income individuals, in Finland over 50 percent of the income received by the top one percent took the form of income from capital. Only 14 percent of their incomes were capital income as late as 1990 . The authors of a recent report on the trends in top income shares in Finland conclude that "the decline in income progressivity since the mid $1990 \mathrm{~s}$ is a central factor explaining the increase in top income shares in Finland." ${ }^{156}$ Somewhat similarly, in Sweden the top incomes have increased dramatically over the past two decades, as in AngloSaxon countries but unlike Continental European countries, and much of this increase is due to capital gains and other forms of income from capital. ${ }^{57}$

Countries: New Insights from the Luxembourg Income Study, 4 SOcIO-ECONOMIC REV. 486, 490 tbl.1 (2006).

54 Id.

55 KENWORTHY, supra note 52.

56 Marja Riihelä, Risto Sullström \& Matti Tuomala, Trends in Top Income Shares in Finland (Gov't Inst. for Econ. Research Fin. (VATT), Discussion Paper No. 371, 2005), available at http://www.vatt.fi/file/vatt_publication_pdf/k371.pdf.

57 Jesper Roine \& Daniel Waldenstom, Top Incomes in Sweden over the Twentieth 
Gustafsson and Jansson said that if the tax system prior to the tax reforms in the early 1990s were in place in Sweden during the 1990s, top- income earners would have had to pay considerably more capital gains tax. ${ }^{58}$

\section{Neutralizing the Forces of Globalization}

Based upon these trends in changing tax structures, if citizens are to retain the ability to choose the goods and services they would like to provide to themselves collectively through democratically elected institutions, and to use the tax system to achieve a more socially acceptable distribution of income, the forces of globalization that are in large part responsible for these trends will have to be neutralized. The most obvious way for that to happen is for countries to agree to coordinate and harmonize aspects of their tax systems, particularly as they relate to the taxation of income from capital.

There is a huge debate in the tax literature over the relative merits of tax competition ${ }^{59}$ and tax harmonization. ${ }^{60}$ This is not the place to review the merits of those arguments, but we would only note that if the interconnected international forces that are constraining tax structures and making it difficult if not impossible to tax income from capital are to be neutralized, it would appear to require more of the types of coordination and harmonization that

Century (Stockholm Sch. of Econ., Working Paper Series in Economics and Finance, Working Paper No. 602, 2005).

58 Björn Gustafsson \& Birgitta Jansson, Top Incomes in Sweden over Three-Quarters of a Century: A Micro Data Approach, 32 CAMBridge J. ECON. 963, 970-71 (2008).

59 Chris Edwards \& Daniel L. Mitchell, Global Tax Revolution: The Rise of Tax Competition and the Battle to Defend It (2008); Julie Roin, Competition and Evasion: Another Perspective on International Tax Competition, 89 GEO. L.J. 543 (2001); Tsilly Dagan, Competing for Business, 36 INTERTAX 201 (2008); see also Tsilly Dagan, The Costs of International Tax Cooperation (Mich. Law \& Econ., Research Paper No. 02-007, 2002), available at http://ssrn.com/abstract=3153733; Tsilly Dagan, Just Harmonization, U. BRITISH COLUMBIA L. REV. (forthcoming 2010).

60 Yariv Brauner, An International Tax Regime in Crystallization, 56 TAX L. REV. 259 (2003). On efforts for harmonization in the European Union, see generally Adolfo J. Martin Jimenez, Towards Corporate Tax Harmonization in the European COMMUNiTy: An Institutional and Procedural ANalysis (1999); Carlo Pinto, Tax Competition and EU law (2003); TAX CompetiTion in Europe (Wolfgang Schon ed., 2003); INTRODUCTION TO EUROPEAN TAX LAW: DIRECT TAXATION (Michael Lang et al. eds., 2008); MALCOLM GAMMIE ET AL., ACHIEVING a Common Consolidated Corporate TaX Base in the EU (2005); Towards a Homogeneous EC Direct TAX LaW (Ceclie Brokelind ed., 2007). 
have been suggested by commentators and in government forums over the past decade, such as the following:

First, building on the OECD and EU initiatives to prevent harmful tax competition, additional steps are required to challenge those countries that seek to artificially attract passive investment income. ${ }^{61}$

Second, the OECD recently modified Articles 26 (Exchange of Information) in its model income tax treaty, and its model Tax Information Exchange Agreement (TIEA) to provide for the exchange of information in civil as well as criminal tax matters, to not require suspicion of criminal conduct before an exchange is required, and to override bank secrecy provisions in domestic laws. However, the requirements for the exchange of information from financial institutions must go much further, be put on a multilateral basis, and require the comprehensive and automatic exchange of all information relating to payments from financial institutions. ${ }^{62}$

Third, the United Nations Committee of Experts on International Cooperation in Tax Matters should be upgraded from its current expert status to intergovernmental status in order to recognize the important political nature of its work, and a strengthened version of its code of conduct for cooperation in combating international tax evasion should be widely endorsed. ${ }^{63}$ Consideration might also be given to the UN establishing a world tax organization that, among other things, would assist in coordinating and harmonizing domestic tax systems with a view to ensuring that all income from capital will be taxed at a reasonable rate. ${ }^{64}$

Fourth, the European Commission recently adopted a Communication, Promoting Good Governance in Tax Matters, in which it urged all member states to take action, among other things, to ensure effective administrative cooperation in the assessment of taxes and recovery of tax claims and to improve the functioning of the Savings Tax Directive - which provides for the multilateral, automatic exchange of information on interest from bank accounts paid to individuals - by extending the scope of the Directive

61 See generally Reuven S. Avi-Yonah, The OECD Harmful Tax Competition Report: A Tenth Anniversary Retrospective, 34 BROOK. J. INT'L L. 783 (2009).

62 Cynthia Blum, Sharing Bank Deposit Information with Other Countries: Should Tax Compliance or Privacy Claims Prevail?, 6 FLA. TAX REV. 579 (2005).

63 See Michael J. McIntyre, United Nations Code of Conduct on Cooperation in Combating International Tax Evasion (Wayne State Univ. Law School, Research Paper No. 08-12, 2008), available at http://ssrn.com/abstract $=1118805$.

64 Frances M. Horner, Do We Need an International Tax Organization?, 24 TAX NOTES INT'L 179 (2001). 
to intermediate tax-exempt structures and to income equivalent to interest obtained through investments in some innovative financial products. ${ }^{65}$

Fifth, capital exporting countries should cooperate in strengthening the taxation of the passive and other easily diverted income of controlled foreign corporations (CFCs). ${ }^{66}$

Sixth, countries should impose a refundable withholding tax on payments to all countries that do not provide for automatic exchange of information. ${ }^{67}$ The right of countries to tax income from capital at source should be reinforced.

Seventh and finally, for corporate tax, the adoption of unitary taxation with formula apportionment coupled with agreement on an acceptable range of corporate tax rates would appear to be essential. ${ }^{68}$

65 Communication from the Commission to the Council, the European Parliament and the European Economic and Social Committee: Promoting Good Governance in Tax Matters, COM (2009) 201 final (Apr. 28, 2009), available at http://eur-lex.eur opa.eu/LexUriServ/LexUriServ.do?uri=COM:2009:0201:FIN:EN:PDF.

66 See Reuven S. Avi-Yonah, Tax Competition and Multinational Competitiveness: The New Balance of Subpart F, 18 TAX NOTES INT'L 1575 (1999).

67 Reuvan S. Avi-Yonah, The Structure of International Taxation: A Proposal for Simplification, 74 TEX. L. REV. 1031 (1996).

68 Kimberly Clausing \& Reuven Avi-Yonah, Reforming Corporate Taxation in a Global Economy: A Proposal to Adopt Formulary Apportionment (The Hamilton Project, Brookings Inst., Discussion Paper No. 2007-08, 2007), available at http:// www.brookings.edu/papers/2007/06corpsoratetaxes_clausing.aspx. 
